\title{
TELEVISION, AN INSTRUMENT FOR AND A MIRROR OF HEALTH AND HEALTH SERVICES
}

Tricia Close-Koenig

Université de Strasbourg

tkoenig@unistra.fr

Angela Saward

Wellcome Collection

a.saward@wellcome.org

Jessica Borge

School of Advanced Study

University of London

jessica.borge@sas.ac.uk

\begin{abstract}
This thematic issue of VIEW brings together articles that show how television has been an instrument for, as well as a mirror of, public service and specifically health services. Two approaches to this are featured and teased out. The first approach concerns health communication and campaigns, where information is diffused via television and strengthened or reinforced by visual and filmic means. The second concerns the structures that offer, manage and model norms of health and healthcare services. In introducing elements of the history of health, we hope to draw attention to the intersection of public health and television over the twentieth century, such that thinking about the relationship between them might change our understanding of both.
\end{abstract}

Keywords: history of television, history of health, health services, public health, Europe

In these months of the Covid-19 pandemic, health has become a prominent focus of media and television, and not without contention. Television news and current affairs shows have actively communicated preventive measures and restrictions within regional, national and international spaces, but in the deluge of information and advice, the media (including social media) have also been thought by some to misconstrue or exaggerate dangers and risks of the infection. Although the articles in this issue were written before the Covid-19 outbreak, there are important insights made here that are relevant to current questions we are (or should be) reflecting upon, such as the influence of media on political decisions and the reception of those decisions. The articles in this issue delve into such questions and contribute to understanding the role that television has had in mediating public and political spheres in issues of health and in times of public health crisis. Public health is rife with political, economic, commercial, social, emotional and personal interests and in times of crisis the conflicts and tensions between these are particularly apparent. Taking a historical look at the role of media, and specifically television, in health-related issues brings to the forefront just how television can (and has) operate(d) in structuring our daily lives and habits and in accepting (or not) the role of the state and other institutions of power in our well-being. 
This special issue of VIEW is largely the product of the 2019 conference Tele(visualising) Health: TV, Public Health, its Enthusiasts and its Publics organised by the ERC-funded BodyCapital project (Université de Strasbourg) and hosted by the Centre for History in Public Health - London School of Health and Tropical Medicine (LSHTM). ${ }^{1}$ This was one in a series of three conferences that examine the relationship between television, the body and health practices over the twentieth century across national and political contexts, with the 2018 Broadcasting health and disease conference organised in collaboration with Wellcome Collection and the 2020 Locating medical television conference organised in collaboration with the Science Museum. This thematic issue of VIEW on the history of health and television includes six articles based on presentations from the Tele(visualising) Health conference, and four additional articles on the topic. We have brought together researchers and archivists from different fields (history of science, history of medicine, communication, media studies) working on the history of television in Great Britain, France and Germany (West and East) (the focus of the ERC BodyCapital project), but also Italy and the United States, effectively combining disciplines and approaches. The online format of VIEW: Journal of European Television History \& Culture with embedded television excerpts within the article text, allowing the excerpts to speak to the reader, is particularly interesting as it endorses the BodyCapital project premise that visuals are not merely representative, but have heuristic and analytic meanings.

Our aim is to bring the history of health and medicine to the attention of historians of television and media. In this editorial, we draw attention to some points of reference in the history of health of the twentieth century that may not be familiar to historians of television and media. In offering these threads, we hope to weave them into the history of television narratives. In this issue, we address the relationship between TV and public health over the second half of the twentieth century and trace economic, sociological and technical changes and continuities. This will complement recent collective publications on the topic, including the 2019 Gesnerus thematic issue entitled 'Broadcasting Health and Disease: Bodies, Markets and Television, 1950s-2000s', which aims to introduce the emerging field of healthrelated audiovisuals to medical historians with case studies that identify and unpack the centrality of television for the history of medicine and health; the 2020 publication Body, Capital and Screens. Visual Media and the Healthy Self in the 20th Century, which explores the performative and interactive power of television and film on individual health understandings, perceptions and practices in terms of economic developments; and the 2020 publication Discourses of Care. Media Practices and Cultures, which interrogates the agency of media (broadly speaking) in discourses of care. $^{2}$ More significantly, we hope this issue of VIEW will bring to the foreground that thinking about the relationship between public health and television might change our understanding of both. This necessitates intersecting the history of television and the history of health - two broad themes in twentieth century history with concurrent chronologies. The concurrence of these historical threads, however, is such that, in Europe and North America, there are blurred edges between them and any chronological timelines would not run parallel, but would weave in and out. This we witness in cases where the medical context pushed television technically, such as the televising of live surgical procedures or tele-medicine. ${ }^{3}$

An overview of the history of health in the twentieth century involves considering the changing face of medical care, treatment, technologies and institutions, in addition to the changing role of the state in managing healthcare and prevention. ${ }^{4}$ By the early twentieth century, varying levels of state welfare had been established in most European countries, for example, to ensure accident and disability insurance, such as the social and health insurance in late nineteenth century Germany under Otto von Bismarck. By the mid-twentieth century, following two world wars and resultant population worries, states were increasingly concerned with well-being and public health in the rationalising of body capital. State health care systems, such as Sécurité Sociale in France (1946) and the National Health Service in Great Britain (1948), were introduced as health became a political and economic issue.

Further, the focus on healthcare shifted from keeping people alive at the turn of the twentieth century to keeping them fit at the dawn of the twenty-first. The role of medicine in daily lives (especially in Western populations) increased significantly from the 1940s with vaccination campaigns (diphtheria, tetanus, poliomyelitis, smallpox, measles, mumps, rubella), the availability of antibiotics (streptococcal and staphylococcal infections, gonorrhoea, syphilis, and other infections), as well as diagnostic technologies. Herein, the threat posed by many previously fatal illnesses was receding and was essentially replaced by diseases (cancers, etc.) and chronic conditions (cardiovascular, etc.) that 
T. Close-Koenig et al., Television, an Instrument for and a Mirror of Health and Health Services

were linked to lifestyle and individual behaviour. Nonetheless, there are numerous examples, and perhaps most notably HIV-AIDS in the 1980s, that challenged the discourse that medicine and healthcare had the upper hand in the fight against disease.

At the same time, televisions became increasingly common in the homes of large numbers of the public in Europe and North America from the mid-1950s. That is, in a period in which ideas about the public's health, the problems that it faced and the solutions that could be offered were changing. Public health professionals were enthusiastic about how television could reach the population and it was assimilated into public health education and prevention campaigns. But, paradoxically, it was a contributing factor to those new public health problems as health problems could be worsened by the unchecked consumption of TV. Watching TV was part of a shift towards more sedentary lifestyles and provided a vehicle through which products that were damaging to health, such as alcohol, cigarettes and unhealthy food, could be advertised to the public. The rapid and massive success of television from the mid-1950s makes it a medium that intervenes in medical issues, as a mirror, an instrument, and a possible menace.

The articles selected for this issue take into consideration evolving policies and social attitudes of health through historical studies of television programmes. This is featured in a variety of programme genres, as illustrated by Hannah Selby and Silvia Leonzi et al. Looking at British programmes dealing with mental health as a transcendent theme working across genre and format, Hannah Selby raises the question of balance in a corpus encompassing the 1950s through to the 1990s. This is accompanied by contextual summaries of the state of mental health care in Britain during these decades. Selby's paper culminates in the rise of 'therapy TV', and some observations on the centrality of televisual discussion in cultural dialogues about mental health.

Silvia Leonzi, Giovanni Ciofalo, Lorenzo Ugolini and Fabio Ciammella chart the influence that scientific, medical and health informational material has had on the evolution of not only TV programme genres, but also arguably on the role health has on society itself via the engrossing dynamics of health storytelling. They analyse the evolution of what they call 'healthentainment' programmes over three TV series aired on RAI in Italy from 1982 onwards, spanning across two 'eras' of societal and technological change.

In this issue, we also look to situate television in the history of health. In this respect, there are a number of studies that examine how television was grasped and used in the efforts and campaigns to curb or modify behaviour away from risky conduct, such as those undertaken by Emily Vinson, Susanne Vollberg, Angela Saward and Pascale Mansier.

The issue opens with Emily Vinson's case study on the long career of the eminent - and perhaps little-known outside of the USA - social psychologist and behavioural scientist Dr Richard I. Evans and his work on juvenile behaviour. Vinson, audiovisual archivist and curator of the KUHT and KUHF Collections at the University of Houston Libraries Special Collections, provides a useful comparative model revealing how early television gave space to health innovators who could develop their practice using the commercial (versus state sanctioned) model of broadcasting. With psychology as a subject proving peculiarly suitable for the medium, Evans, appearing on TV himself, sought to popularise it as a scientific discipline. Programmes produced under his supervision used the evolving genre of the docudrama, engaging audiences with tales of preventable juvenile delinquency, a hot topic in the 1960s. Evans went on to develop social inoculation theory in his work on the health education of smoking and teenagers; it was later extrapolated to become the long running 'Just Say No' campaign, which delivered mixed results.

Susanne Vollberg's contribution studies the televisual presentation of nutritional and physical activity in the context of West German television between the 1950s and 1980s, following the trend for slimming and the rise in heart disease. In particular, this paper introduces us to emblematic German campaign nudge devices, including 'Trimmy', a male motivational mascot in training shorts and widely-recognised visual embodiment of the "Trimm Dich! Mit Sport!" campaign, which reached a staggering 94 per cent public awareness.

In Angela Saward's article, the forgotten history of a British television programme on venereal disease named 'Health Hazards' (1973) is unpacked using primary source-based empirical research. ${ }^{5}$ Saward conducts an investigation into 
the technical production of schools' sexual education programming in the period right before AIDS. Saward's role as a research development specialist at Wellcome Collection, London, has allowed her to delve deep into the archive, bringing to the surface valuable questions on why important TV events, such as 'Health Hazards' (from the series Twentieth Century Focus), become obscured.

Pascale Mansier's article on the 1990s French programme Sidamag explores a sexual education and AIDS prevention programme created for juvenile audiences. Working on a genre she knows well - the health magazine Mansier examines the formats used in the programme. ${ }^{6}$ Not only was this the only health magazine to focus on one illness, it placed particular focus on presenting patient perspectives on television. She presents a quantitative and qualitative survey of the programme's content, together with a history of the conception and production of the show that is enriched with an interview with the producer.

Television was also used to communicate norms of behaviour in line with political contexts. In her article, Sandra Schnädelbach maps how TV became a conduit for communicating the relationship between emotions and behaviour, but also how the socialist state tacitly sanctioned the monitoring of health via emotions and signalled its impact on organic disease using audio-visual means. Television had a special place in the GDR: a high domestic ownership of sets mirrored that of its neighbour, the FDR. Within the socialist model of public health, the role of TV was complementary to face-to-face health messaging. Maladjustment to socialist behavioural norms (or mores) directly affected productivity, creating negative feedback loops, or 'bad vibes', demonstrating how modern life influences stress and health outcomes.

Christian Bonah and Joël Danet, Matthew Melia, and Benjamin Coulomb all illustrate how television held a role in familiarizing viewers on health service structures and politics, and was, at times, a means to contest them in a democratic context.

Matthew Melia explores British comedy, and specifically medical comedy. Melia's article plays on generalised ideologies and architectures of the past (which he characterizes as old and Victorian) and the present/future (as new and modern), as well as class distinctions, which social welfare structures were supposed to erase. Melia considers a selection of emblematic British television comedy series, programmes and films, from Hancock to Britannia Hospital, drawing out scenes and circumstances as reflective of, and feeding into (even provoking) the politics and ideological tensions of the workings of the National Health Service.

Christian Bonah and Joël Danet present three television programmes, from 1957, 1969 and 1982 on social welfare administration that seek to both educate and captivate school audiences, in order to shape and form their attitudes towards it. They bring forth a history of school television and of the social security system in France, placing them in line with documentary trends of that time. The three programmes show more than the subject required: the weather, architecture, clothing styles and even reactions, gestures and silences are used to interweave the social, economic and sanitary determinants of health.

Benjamin Coulomb's study of a French scandal arising from adulterated talcum powder demonstrates the role of television reportage in informing consumers, and for framing evolving consumer policies. In this article, Coulomb explores the mediatisation of the Morhange talcum powder scandal, which was widely covered on French news television between 1972 and 1981. This coverage engendered the long-lasting collective memory of the Morhange scandal, even overshadowing more severe cosmetics and health disasters not covered on television.

There is also notable attention, in this group of articles, granted to young audiences. Teenagers emerged as a distinct socio-economic group post-1945. ${ }^{7}$ Health campaigners and the media directed their attentions to teens, who were captive audiences as television became increasingly common in educational settings. There was an assumption that, as television was a modern conduit for health messaging, it was eminently suitable for communication aimed at young people. Controversies around this assertion are picked up in these articles, especially in light of new research into audience reception, which has historically been hard to gauge. This is taken on by Vinson, Saward, and Mansier who 
explore specific television programmes that targeted teen audiences, as well as Bonah and Danet who discuss school television programmes.

As a collection of European studies (including a study from the United States), this issue provides explanations and elements of different national broadcasting systems and different health systems that bring us closer to establishing comparative perspectives. This is frequently complicated by the very different television archiving systems within each country, ${ }^{8}$ but comparison of genres and themes is also muddled by the difficulty of translating television terminology. For example, several articles focussed on the 'magazine,' thereby leading us to wonder if the French magazine genre is the same as that in Britain or in Italy, as well as on the distinction between telemagazine and tele-magazine, or even cinemagazine, ${ }^{9}$ or the fine lines between these and news programmes or current affairs programmes. The relevance of (different) magazine genres for health education is indeed an interesting topic for future comparative studies. The value in gathering any corpus of multi-national work together lies in gaining a shared understanding of such questions and an awareness of the many variables that exist within transnational studies.

In this issue, 'Tele(visualising) Health: TV, Public Health, its Enthusiasts and its Publics', we bring together studies that explore how and when health was tele-visualised. The articles necessarily cross different genres of television programmes and critical approaches. They all touch, some more directly than others, on health education, on modelling behaviour and on individual practices. These studies consistently iterate specific case studies of expectations and enthusiasms from the 1950s onward, including the prevalent sense that television could influence behaviour, and as such act as a powerful tool to communicate health and preventive measures. We can see in these articles how television has been an instrument for, as well as a mirror of public service, and specifically health services. Two approaches to this are featured and teased out. The first approach concerns health communication and campaigns, where information is diffused via television and strengthened or reinforced by visual and filmic means. The second concerns the structures that offer, manage and model norms of health and healthcare services.

\section{Authors" note}

The authors acknowledge that the preparation of this article and the editorial preparation of the thematic issue, within the ERC BodyCapital project, received funding from the European Research Council (ERC) under the European Union's Horizon 2020 research and innovation programme (grant agreement No 694817).

\section{Notes}

1. We extend notable thanks to the organizing committee of the conference Alex Mold (who coined the title), Virginia Berridge, and Ingrid James at LSTHM, as well as Christian Bonah, Anja Laukötter, Tricia Close-Koenig and other members of the ERC BodyCapital research team.

2. "Special Issue: Broadcasting Health and Disease: Bodies, Markets and Television, 1950s-2000s," Gesnerus 76, no. 2 (2019); Christian Bonah and Anja Laukötter, eds., Body, Capital, and Screens. Visual Media and the Healthy Self in the 20th Century (Amsterdam: Amsterdam University Press, 2020); Amy Holdsworth, Karen Lury, and Hannah Tweed, eds., Discourses of Care. Media Practices and Cultures (New York: Bloomsbury Academic, 2020). These can be situated within a growing body of visually oriented research on medicine and science, including Christian Bonah, David Cantor, and Anja Laukötter, eds., Health Education Films in the Twentieth Century (Rochester: University of Rochester Press, 2018), https://medfilm.unistra.fr/wiki/ Health_education_films; Timothy Boon, Films of Fact. A History of Science in Documentary Films and Television (London: Wallflower, 2008); Lisa Cartwright, Screening the Body. Tracing Medicine Visual Culture (Minneapolis: University of Minnesota Press, 1995).

3. Cf. Joël Danet, "Approches du Geste Chirurgical dans le Cinéma Documentaire: Un Geste Exemplaire, un Geste Cinégénique, un Geste Comptable" [The Surgical Gesture in Documentary Cinema: An Exemplary Gesture, a Cinematographic Gesture, an Accounting Gesture], in Approches du Geste Chirurgical (20e-21e siècles): Histoire, Littérature, Philosophie, Arts Visuel 
[Approaches to the Surgical Gesture ( $20^{\text {th }}-21^{\text {st }}$ century): History, Literature, Philosophy, Visual Arts], eds. Thomas Augais and Julien Knebusch (Chêne-Bourg: editeur Georg, 2020), 191-209; David Serlin, "Performing Live Surgery on Television and the Internet since 1945," in Imagining IIIness: Public Health and Visual Culture, ed. David Serlin (Minneapolis: University of Minnesota Press, 2010), 223-44; Jeremy A. Greene, "When Television Was a Medical Device. On Technology and Health Care," Humanities 38, no. 2 (2017), https://www.neh.gov/humanities/2017/spring/feature/when-television-was-medical-device

4. For an overview of the history of medicine in the twentieth century, cf. William Archibald Robson Thomson and Philip Rhodes, "Medicine in the 20th Century," Encyclopaedia Britannica, https://www.britannica.com/science/history-of-medicine/ Medicine-in-the-20th-century; Roger Cooter and John Pickstone, eds., Companion to Medicine in the Twentieth Century (London: Routledge, 2016); Stanley Joel Reiser, Medicine and the Reign of Technology (New York: Cambridge University Press, 1978).

5. She has also recently, similarly unpacked, the history of the University of London's Audio-visual Centre (ULAVC) held at Wellcome Collection: Angela Saward, “Television Discourses': How the University of London's Audio-Visual Centre professionalised and democratised the televisual lecture for postgraduate medical students," Gesnerus 76, no. 2 (2019): 192-224, https://doi.org/10.24894/Gesn-en.2019.76010.

6. Pascale Mansier, "Les Magazines de Santé à la Television Depuis les Années 1950" [Health Magazines on Television since the 1950s], Le Temps des Médias 2, no. 23 (2014): 241-4, http://www.histoiredesmedias.com/Les-magazines-de-sante-ala.html; Pascale Mansier, "La Place Accordée aux Informations Scientifiques dans les Magazines de Santé Télévisuels" [Scientific Information in Television Health Magazines], Les Enjeux de l'Information et de la Communication 20, no. 2 (2019): 43-54, https://lesenjeux.univ-grenoble-alpes.fr/2019/dossier/03-la-place-accordee-aux-informationsscientifiques-dans-les-magazines-de-sante-televisuels.

7. See for example, Bill Osgerby, Youth Media (Abingdon: Routledge, 2004) or Grace Palladino, Teenagers: An American History (New York: Basic Books, 1996).

8. This was traced out in detail in: Jessica Borge, Tricia Close-Koenig and Sandra Schnädelbach, "Introduction. The Science of Television: Television and its Importance for the History of Health and Medicine" (Special Issue: Broadcasting Health and Disease: Bodies, Markets and Television, 1950s-2000s), Gesnerus 76, no. 2 (2019): 153-71, esp. 157-63, https:// doi.org/10.24894/Gesn-en.2019.76008.

9. Emily Crosby and Linda Kaye, eds., Projecting Britain: The Guide to British Cinemagazines (London: British Universities Film \& Video Council, 2008).

\section{Biographies}

Tricia Close-Koenig is a historian of medicine and science. She is currently coordinator and researcher of the ERC funded project, The healthy self as body capital (BodyCapital), and adjunct lecturer at the Université de Strasbourg. Her current research focuses on a history of milk, nutrition and dietary norms through Canadian audiovisual archives. In parallel, she also works on the history of pathology tissue collections and the cataloguing practices that accompany them.

Angela Saward has been working with audio-visual archives for many years, researching, licensing and managing the curatorial lifecycle of audio, film and video. Currently, she is Research Development Specialist (Moving Image and Sound), Wellcome Collection, London, working with Wellcome's unique and distinctive collections across many formats supporting colleagues and cross-cultural partners but with a special emphasis on the audio-visual. She serves on the Steering Group for London's Screen Archives and is an active member of FOCAL and AMIA. She has a business master MA MTA and a first degree in English Literature.

Jessica Borge is an interdisciplinary researcher in the field of Contemporary British History, with a specialism in the intersection of business, society and media. She holds a visiting fellowship in digital humanities at the School of Advanced Study, University of London and is currently Digital Collections (Scholarship) Manager at King's College London Archives and Research Collections. Her monograph, Protective Practices. A History of the London Rubber Company and the Condom Business, is published by McGill-Queens University Press. 